Article title: Using E-Portfolios for Meaningful Teaching and Learning in Distance Education in Developing Countries: A Systematic Review

Authors: Mpho-Entle Puleng Modise[1], Patience Kelebogile Mudau[2]

Affiliations: University of South Africa[1]

Orcid ids: 0000-0002-2817-6329[1], 0000-0002-5389-6942[2]

Contact e-mail: mudaupk@unisa.ac.za

License information: This work has been published open access under Creative Commons Attribution License http://creativecommons.org/licenses/by/4.0/, which permits unrestricted use, distribution, and reproduction in any medium, provided the original work is properly cited. Conditions, terms of use and publishing policy can be found at https://www.scienceopen.com/.

Preprint statement: This article is a preprint and has not been peer-reviewed, under consideration and submitted to UnisaRxiv for open peer review.

DOI: 10.25159/UnisaRxiv/000015.v1

Preprint first posted online: 11 May 2021

Keywords: e-portfolios, assessment, self-directed learning, critical thinking skills, reflection, meaningful feedback 


\section{Using E-Portfolios for Meaningful Teaching and Learning in Distance Education in Developing Countries: A Systematic Review}

\section{Mpho-Entle Puleng Modise}

https://orcid.org/0000-0002-2817-6329

University of South Africa

\author{
Patience Kelebogile Mudau \\ https://orcid.org/0000-0002-5389-6942 \\ University of South Africa \\ mudaupk@unisa.ac.za
}

\section{Abstract}

Web-based technology has proven itself indispensable in education, especially in distance education and in developing countries. Technological advances and the Covid-19 pandemic have forced higher education institutions to be innovative in delivering education in their countries. This paper seeks to demonstrate the role and value of e-portfolios as an alternative teaching and learning tool in distance education and the online environment, especially in developing countries. A systematic review of peer-reviewed academic studies of e-portfolios between 2010 and 2020 was conducted. A total of 18 papers were selected according to the inclusion criteria. The review shows that the use of eportfolios is still a relatively new trend in developing countries. The study also revealed that e-portfolios can infuse important skills such as self-directed learning, critical thinking and lifelong learning. These results have the potential to help institutions to creatively design appropriate support tools and strategies alongside the implementation of e-portfolios in their contexts.

Keywords: e-portfolios, assessment, self-directed learning, critical thinking skills, reflection, meaningful feedback

\section{Introduction and Background}

Teaching and learning strategies and methods in higher education institutions (HEIs) have been evolving. Currently, students have direct access to mass communication and information, rapidly developing technologies and the need to acquire relevant skills. In order to keep pace with emerging technology trends in education, HEIs are forced to embrace and increasingly use technology to teach and support students. As a result, HEIS are challenged to provide student-centred learning opportunities (Rodgers et al. 2006) which integrate the use of technology portfolios as an alternative teaching and learning tool in online distance education (DE) environments.

However, the emergence of the Covid-19 pandemic has changed the face of "normal" education delivery and compelled educational institutions to continue providing education to learners using technology as an alternative means (Deslandes and Coutinho 2020; Gurukkal 2020). Web-based technology has over time proven itself to be 
increasingly indispensable in education, and more so in times such as currently experienced.

With the advancement of technology, conventional teaching portfolios have been reinvented with the use of digital portfolios, known as electronic portfolios (eportfolios). The definition of a portfolio has changed, initially being seen as a physical archive for students' finest work (Herbert 1998) or merely a container (Polonoli 2000,4), or a living document (Barrett 2011) and now as a lifelong learning tool. Literature offers many definitions of an e-portfolio, however, consensus among scholars is that the e-portfolio encompasses both a process and a product. As a process, the eportfolio allows students to move beyond learning for the sake of learning and apply knowledge, skills and values found in real-life situations (Jimoyiannis 2012). Eportfolios have become one of the spaces where more flexible forms of computer-based assessment are in alignment with measuring the knowledge and skills that students need to function in an evolving digital age (Bates 2015).

The use of e-portfolios in developing countries is relatively new and in this regard, pose uncertainties with their use, implementation and effectiveness. However, developing countries need to integrate relevant technologies for effective teaching and learning, especially now with the current uncertainties and the need to find alternate methods of teaching and learning. Owing to the growing interest in e-portfolios in higher education (HE) (Chaudhuri and Cabau 2017), there is a need to understand the essence of eportfolio pedagogical affordances and the issues to be dealt with for meaningful use (Oh, Chan, and Kim 2020). The purpose of this paper was to conduct a systematic review of peer-reviewed academic studies of e-portfolios between 2010 and 2020 to investigate and document the way in which e-portfolios can be used for meaningful learning and learner support in HE and DE in developing countries.

\section{Literature Review}

E-portfolios, as a process of learning, include digital artefacts, written reflection on both formal and informal learning experiences, collaborative assignments, community engagement, research activities, and learning achievements (Light, Chen, and Ittelson 2012). Barrett (2011) points out that the e-portfolio uses technologies which allow students to build and organise artefacts in various media types such as audio, video, graphics and texts, thereby developing digital skills needed in this era. In addition, digital tools used allow users to interact with content and to disseminate knowledge and content (Baker-Doyle and Yoon 2020), meaning that users can collaborate by sharing and revising existing content.

The strength of e-portfolios lies in the extensive use of reflective learning practices. Through interaction with content and with others, reflective learning, creatively designed learning activities and continuous feedback and authentic assessment, students first master self-learning and self-evaluation skills and then are able to co-learn and co- 
produce knowledge with peers (Cheng and Chau 2013; De Jager 2019). Studies show that the process of building e-portfolios assists students in becoming active and independent lifelong learners (Beckers, Dolmans, and Van Merriënboer 2016), who, in a technology-enriched space, can cultivate their learning and knowledge through collaborative projects and peer learning. E-portfolios' ubiquity (Roder and Brown 2009) and flexibility (Shroff, Trent, and Ng 2013) mean anyone can participate. Although learners have computing needs, such as relevant digital gadgets, the use of e-portfolios is an important alternative teaching and learning tool for education in developing countries where vast numbers of students do not have the resources to travel to places of education and as a result, rely on DE and online learning.

Portfolio pedagogy can be used for reflection and assessment to showcase skills and achievements, using appropriate communication modalities (Boulton 2014; FitzPatrick and Spiller 2010). However, e-portfolios seem to be far more effective when they are used as a process of learning rather than only as a product (TeachOnline 2014).

Benefits and challenges of using e-portfolios in education are well documented in the literature (Akleh and Wahab 2020; De Jager 2019). Developing countries may realise the benefits of adopting well-designed modules that incorporate e-portfolios in their programmes. Although Bates (2015) argues that e-portfolios are one of the examples of ways in which educationists are gradually developing unique "affordances" of the use of the internet, students in developing countries are faced with major challenges in adopting educational technologies owing to a lack of digital literacy, limited access to the internet, electricity and connectivity. However, the Covid-19 pandemic lockdown revealed that humans are capable of adapting and surviving major changes, however sudden and uncomfortable.

\section{Theoretical Framework}

At the centre of educational e-portfolios is the drive for student centeredness; thus the theoretical frameworks guiding this study are social constructivism and self-directed learning theories. Constructivism is a synthesis of multiple behaviouralist and cognitive theories that assist in probing learning and development with the premise that learning is a process in which people construct meaning by making sense of their experiences.

Social constructivism asserts that the "process of knowing is affected by other people and is mediated by community and culture" (Amineh and Asl 2015, 16). Social constructivism requires that teachers situate learning activities in the context of students' lives, thereby enhancing the meaningfulness of their learning experiences. Learning as a social activity (Chugh and Ruhi 2018) acknowledges that learners enter the educational space with preconceived ideas and experiences. Using e-portfolios therefore allows learners to construct new concepts in their personal learning environments based on their experience and current knowledge. 
Self-directed learning theory on the other hand, is "a process in which individuals take the initiative, with or without the help of others, in diagnosing their learning needs, formulating learning goals, identifying human and material resources for learning, choosing and implementing appropriate learning strategies, and evaluating learning outcomes" (Knowles 1975, 18). Morris (2020) asserts that self-directed learning is a critical workplace competence that needs to be fostered in formal educational settings. E-portfolios are supported by constructivist and self-directed learning principles in that learning activities are designed to support students in constructing knowledge and understanding, both individually and collaboratively.

\section{Methodology}

A systematic literature review of peer-reviewed academic papers was conducted with searches from three academic databases - Educational Resource Information Centre (ERIC), Web of Science, and Scopus. The purpose of this systematic review was to identify and present empirical evidence from the existing literature (Pham et al. 2014) of the way in which e-portfolios can effectively be used to teach and support learning in HE and DE. The review question driving the study was: "How can e-portfolios be used for meaningful teaching and learning in distance education for developing countries?" This research purposefully selected academic journal papers based on the inclusion and exclusion criteria (Table 1).

Table 1: Inclusion and exclusion criteria

\begin{tabular}{|l|l|}
\hline Inclusion Criteria & Exclusion Criteria \\
\hline Published 2010 to 2020 & Published before 2010 \\
\hline $\begin{array}{l}\text { Papers published in English } \\
\text { only }\end{array}$ & Papers in languages other than English \\
\hline Primary empirical research & Reviews or theoretical articles \\
\hline $\begin{array}{l}\text { Journal articles, full-text, open } \\
\text { access }\end{array}$ & $\begin{array}{l}\text { Grey literature, blogs, fee-based papers, newspapers, e- } \\
\text { books, etc. }\end{array}$ \\
\hline Developing countries & Developed countries \\
\hline $\begin{array}{l}\text { HE (college, university, post- } \\
\text { secondary, tertiary) }\end{array}$ & $\begin{array}{l}\text { Not basic education (high school, primary school } \\
\text { education), corporate education and training, technical } \\
\text { and vocational education and training }\end{array}$ \\
\hline DE (e-learning, blended) & Face-to-face education, contact universities \\
\hline $\begin{array}{l}\text { About e-portfolios (web-based, } \\
\text { digital portfolios) }\end{array}$ & $\begin{array}{l}\text { Non-educational, not about e-portfolios or other types } \\
\text { of e-portfolio (e.g. PDF, hard-copy/traditional } \\
\text { portfolio) }\end{array}$ \\
\hline Educational e-portfolios & $\begin{array}{l}\text { Non-educational, e.g. professional development } \\
\text { portfolios, showcase portfolios }\end{array}$ \\
\hline
\end{tabular}

The refining process identified 190 papers (Figure 1) which were then uploaded to the EPPI-Reviewer software for further screening and synthesis. EPPI-Reviewer is a "web- 
based software program for managing and analysing data in literature reviews" (EPPICentre 2021, para 1), developed and maintained by the EPPI-Centre at the University College in London.

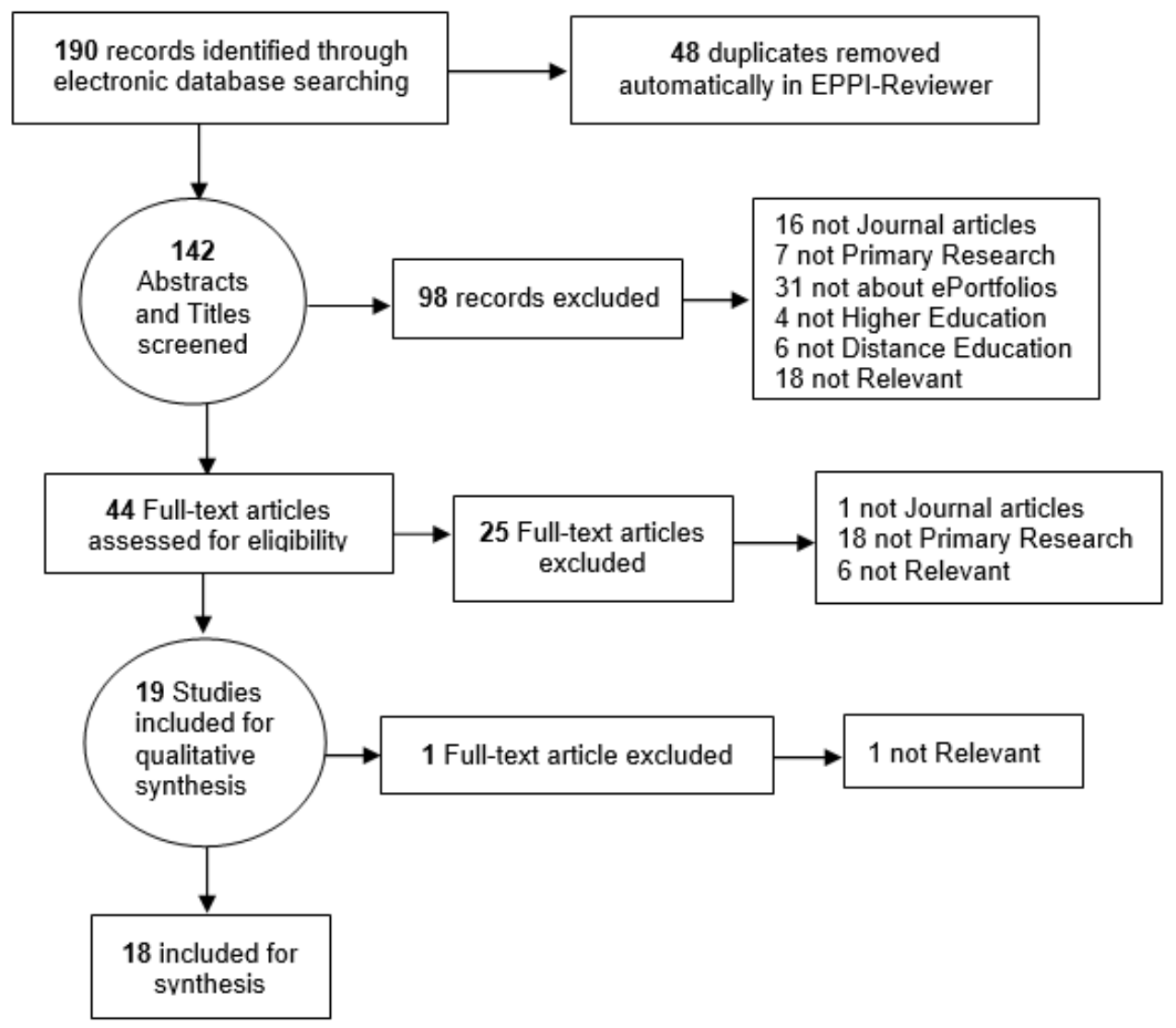

Figure 1: Flow diagram (Adapted from Moher et al. 2009)

The 18 selected studies listed in Table 2 were qualitatively synthesised using the extensive coding system developed by Bond et al. (2020). Systematic review studies use content analysis (Zawacki-Richter et al. 2018), which was also relevant for the data analysis in this study. Coding reports were generated from the EPPI-Reviewer and exported to the researchers for further analysis. To minimise bias and ensure interrater reliability, a measure of the agreement between two researchers was calculated using Cohen's kappa (Pérez et al. 2020). To achieve this, items were screened in small batches, the kappa was calculated, and agreements and disagreements were discussed, resulting in Cohen's kappa improving to 0.76 . 
Table 2: Overall findings reported in the reviewed papers

\begin{tabular}{|c|c|c|}
\hline Authors (date) & Overall Findings & Country \\
\hline $\begin{array}{l}\text { Abd-Wahab et al. } \\
\text { (2016) }\end{array}$ & $\begin{array}{l}\text { Reflection, deep learning, instantaneous } \\
\text { and meaningful feedback, self-regulation } \\
\text { improved, digital skills }\end{array}$ & Malaysia \\
\hline $\begin{array}{l}\text { Akleh and Wahab } \\
\text { (2020) }\end{array}$ & $\begin{array}{l}\text { Reflection, digital skills, learning from } \\
\text { peers, continuous and authentic } \\
\text { assessment, learning by doing }\end{array}$ & Bahrain \\
\hline $\begin{array}{l}\text { Carl and Strydom } \\
\text { (2017) }\end{array}$ & $\begin{array}{l}\text { Digital skills, metacognitive learning, } \\
\text { deep learning, lifelong learning }\end{array}$ & South Africa \\
\hline $\begin{array}{l}\text { Chau and Cheng } \\
\text { (2010) }\end{array}$ & $\begin{array}{l}\text { Reflection, self-regulation improved, } \\
\text { learning from peers, instantaneous and } \\
\text { meaningful feedback, understanding } \\
\text { concepts }\end{array}$ & Hong Kong \\
\hline $\begin{array}{l}\text { Cheng and Chau } \\
\text { (2013) }\end{array}$ & $\begin{array}{l}\text { Ownership of learning, deep learning, } \\
\text { critical thinking skills, metacognitive } \\
\text { learning, peer learning }\end{array}$ & Hong Kong \\
\hline De Jager (2019) & $\begin{array}{l}\text { Reflective, self-regulation improved, } \\
\text { critical thinking skills, feedback }\end{array}$ & South Africa \\
\hline De Swardt et al. (2019) & $\begin{array}{l}\text { Critical thinking, reflection, ownership of } \\
\text { learning, learning by doing, metacognitive } \\
\text { learning }\end{array}$ & South Africa \\
\hline $\begin{array}{l}\text { Kabilan and Khan } \\
\text { (2012) }\end{array}$ & $\begin{array}{l}\text { Improve content knowledge, learning } \\
\text { from peers, deep learning, digital skills }\end{array}$ & Malaysia \\
\hline $\begin{array}{l}\text { Lukitasari, Hasan, and } \\
\text { Sukri (2020) }\end{array}$ & $\begin{array}{l}\text { Continuous and authentic assessment, } \\
\text { engagement (increased/enhanced), deep } \\
\text { learning, learning from peers, lifelong } \\
\text { learning }\end{array}$ & $\begin{array}{l}\text { Malaysia } \\
\text { Bangladesh } \\
\text { Indonesia }\end{array}$ \\
\hline $\begin{array}{l}\text { Mapundu and Musara } \\
\text { (2019) }\end{array}$ & $\begin{array}{l}\text { Self-regulation improved, flexibility and } \\
\text { convenient, continuous and authentic } \\
\text { assessment, interaction and collaboration, } \\
\text { authentic learning }\end{array}$ & South Africa \\
\hline $\begin{array}{l}\text { Mohamad, Embi, and } \\
\text { Nordin (2016) }\end{array}$ & $\begin{array}{l}\text { Reflective, deep learning, digital skills, } \\
\text { self-regulation improved, metacognitive } \\
\text { learning }\end{array}$ & South Africa \\
\hline Harun and Jhee (2012) & $\begin{array}{l}\text { Reflective, productive learning, } \\
\text { continuous and authentic assessment, } \\
\text { instantaneous and meaningful feedback, } \\
\text { interaction }\end{array}$ & Malaysia \\
\hline Sellami (2017) & Reflection, feedback, deep learning & Tunisia \\
\hline $\begin{array}{l}\text { Shroff, Trent, and Ng } \\
\text { (2013) }\end{array}$ & $\begin{array}{l}\text { Ownership of learning, self-regulation } \\
\text { improved, critical thinking, continuous } \\
\text { and authentic assessment, learning by } \\
\text { doing }\end{array}$ & Hong Kong \\
\hline
\end{tabular}




\begin{tabular}{|l|l|l|}
\hline Authors (date) & Overall Findings & Country \\
\hline $\begin{array}{l}\text { Strydom and Barnard } \\
(2017)\end{array}$ & $\begin{array}{l}\text { Ownership of learning, Critical thinking, } \\
\text { continuous and authentic assessment, self- } \\
\text { regulation improved, engagement } \\
\text { (increased/enhanced) }\end{array}$ & South Africa \\
\hline $\begin{array}{l}\text { Thang, Lee, and } \\
\text { Zulkifli (2012) }\end{array}$ & $\begin{array}{l}\text { Digital skills, deep learning, reflection, } \\
\text { self-regulation improved, critical thinking }\end{array}$ & Malaysia \\
\hline Van Wyk (2017) & $\begin{array}{l}\text { Reflective, enhance content knowledge, } \\
\text { continuous and authentic assessment, } \\
\text { ownership of learning, interaction, self- } \\
\text { regulation improved }\end{array}$ & South Africa \\
\hline $\begin{array}{l}\text { Yang, Tai, and Lim } \\
\text { (2016) }\end{array}$ & $\begin{array}{l}\text { Reflective, ownership of learning, } \\
\text { metacognitive learning, self-regulation } \\
\text { improved, critical thinking }\end{array}$ & Hong Kong \\
\hline
\end{tabular}

\section{Findings}

The overall findings of the reviewed papers positively correlate with the idea that eportfolio is a powerful tool to promote learning (see Table 2). Three interlinked themes emerged: (1) reflective learning in e-portfolios; (2) instantaneous and meaningful feedback; and (3) continuous and authentic assessment. The fourth theme present the challenges highlighted in the included studies (Table 3). Digital skills and self-directed learning, although crucial in $\mathrm{HE}$ and $\mathrm{DE}$, are automatic by-products of e-portfolios because learners gain multimedia and independent learning skills through developing eportfolios (Thang, Lee, and Zulkifli 2012).

Table 3: Challenges of e-portfolios reported in the reviewed papers

\begin{tabular}{|l|l|}
\hline Source & Identified challenges \\
\hline $\begin{array}{l}\text { Abd-Wahab et al. } \\
(2016)\end{array}$ & $\begin{array}{l}\text { Internet } \\
\text { Facilitation of learning } \\
\text { Plagiarism } \\
\text { Time-consuming }\end{array}$ \\
\hline $\begin{array}{l}\text { Akleh and Wahab } \\
(2020)\end{array}$ & $\begin{array}{l}\text { Hardware and software challenges } \\
\text { Time-consuming } \\
\text { Workload for teachers } \\
\text { Security and privacy issues } \\
\text { Digital literacy }\end{array}$ \\
\hline $\begin{array}{l}\text { Carl and Strydom } \\
(2017)\end{array}$ & Cognitive overload \\
\hline $\begin{array}{l}\text { Chau and Cheng } \\
(2010)\end{array}$ & $\begin{array}{l}\text { Workload (requiring extra time and effort from } \\
\text { teachers) } \\
\text { Teacher identity }\end{array}$ \\
\hline De Jager (2019) & $\begin{array}{l}\text { Digital literacy } \\
\text { Ethical problems (plagiarism) }\end{array}$ \\
\hline
\end{tabular}




\begin{tabular}{|c|c|}
\hline Source & Identified challenges \\
\hline $\begin{array}{l}\text { De Swardt et al. } \\
\text { (2019) }\end{array}$ & Internet connectivity \\
\hline Harun and Jhee (2012) & $\begin{array}{l}\text { Workload for teachers } \\
\text { Digital literacy } \\
\text { Assessing and moderating students e-portfolios }\end{array}$ \\
\hline $\begin{array}{l}\text { Kabilan and Khan } \\
\text { (2012) }\end{array}$ & $\begin{array}{l}\text { Internet connection } \\
\text { Negative attitudes/perceptions of learners } \\
\text { Workload for students (weekly submissions) } \\
\text { Time-consuming } \\
\text { Assessment techniques } \\
\text { Ethical problems (plagiarism) }\end{array}$ \\
\hline $\begin{array}{l}\text { Lukitasari, Hasan, and } \\
\text { Sukri (2020) }\end{array}$ & Digital literacy \\
\hline $\begin{array}{l}\text { Mapundu and Musara } \\
\text { (2019) }\end{array}$ & $\begin{array}{l}\text { Time-consuming } \\
\text { Security and privacy issues }\end{array}$ \\
\hline Sellami (2017) & $\begin{array}{l}\text { Lack of awareness } \\
\text { Time-consuming } \\
\text { Workload for students (weekly submissions) }\end{array}$ \\
\hline $\begin{array}{l}\text { Strydom and Barnard } \\
\text { (2017) }\end{array}$ & Lack of ICT skills by faculty \\
\hline $\begin{array}{l}\text { Thang, Lee, and } \\
\text { Zulkifli (2012) }\end{array}$ & $\begin{array}{l}\text { Poor internet connections } \\
\text { Digital literacy } \\
\text { Facilitation of learning (lack of guidance from } \\
\text { instructors) } \\
\text { Time-consuming } \\
\text { Poor ICT facilities }\end{array}$ \\
\hline $\begin{array}{l}\text { Yang, Tai, and Lim } \\
\text { (2016) }\end{array}$ & $\begin{array}{l}\text { Teaching presence } \\
\text { Negative attitudes/perceptions of learners } \\
\text { Ethical problems (plagiarism) }\end{array}$ \\
\hline
\end{tabular}

Of interest is the number of papers on e-portfolios which have been published since 2010. The overall increase of e-portfolio research was prevalent in 2017, as indicated in Figure 2.

Of the 18 selected papers, six were from South Africa, five from Malaysia and four from Hong Kong (Table 2). This study also shows that e-portfolios are mostly used in HEIs in Asian developing countries and in some HEIs in South Africa. 


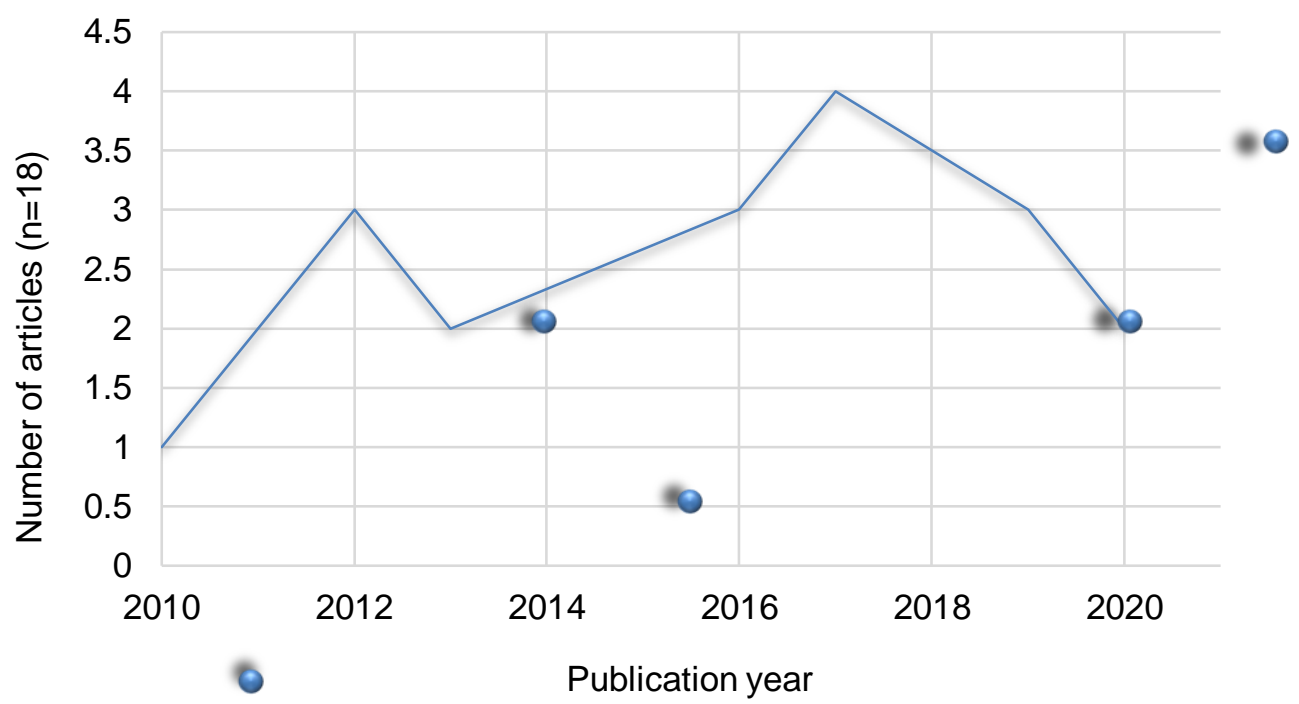

Figure 2: Number of published papers per year (2010-2020)

\section{Discussion}

\section{Reflective Learning in E-Portfolios}

Reflection is considered an integral part of e-portfolios (Bassot 2015) and has been acknowledged to have the power to promote learning and to develop expertise (Ebil, Salleh, and Shahrill 2020). This study found that almost all of the 18 reviewed papers reported reflection to be the most used tool to enhance learning in e-portfolios (Table 2). Ebil, Salleh, and Shahrill $(2020,5800)$ argue that "theoretical roots of reflection are found in constructivism", which gives learners an opportunity to make sense and create meaning of their learning experiences. As "reflective learning is the core of e-Portfolio" (Mohamad, Embi, and Nordin 2016, 233), it offers learners the opportunity to interact with content and with each other to solve problems, helping to create self-confident, self-directed and highly motivation students. Reflective learning has long been believed to develop and improve students' self-directed learning skills (Garrison 1997) which not only helps them to take ownership of their learning but also to gain lifelong learning skills. Van Wyk's (2017) study revealed that the use of e-portfolios in teaching subjects such as Economics in HE enhanced reflective practices of learners. However, Ebil, Salleh, and Shahrill (2020) suggest that reflection can be guided, being a skill that should be encouraged and taught. The studies also revealed that reflective practice gives students the opportunity to adjust their e-portfolios according to feedback and recommendations (Chau and Cheng 2010; De Jager 2019), which gives students the opportunity to analyse past learning experiences and make meaning of new information (Thang, Lee, and Zulkifli 2012). 
Interestingly, reflective learning is also seen as valuable for faculty too, providing them with an opportunity to reflect on their own teaching practices, and to evaluate the course or learning goals (Akleh and Wahab 2020; Kabilan and Khan 2012). E-portfolios thus help faculty to creatively develop courses for tertiary education which result in the use of "relevant and meaningful instructional approaches" (Kabilan and Khan 2012, 1014).

E-portfolios align well with a student-centred approach and constructivist views of learning (Ebil, Salleh, and Shahrill 2020) and learning by doing (Reese 2011), which is "learning from experiences resulting directly from one's own actions, as contrasted with learning from watching others perform" (Reese 2011,1). Moye, Dugger and Starkweather $(2014,22)$ put it simply, saying that "knowing something and knowing how to do something are very different things", which means that the e-portfolio affords students the opportunity to learn by doing and to use technology to solve problems (Moye, Dugger and Starkweather 2014).

\section{Instantaneous and Meaningful Feedback}

As reflection is considered integral to e-portfolios promoting learning and developing expertise, feedback is also a key factor for educational e-portfolios. Mapundu and Musara $(2019,203)$ argue that feedback "helps with the interaction of involved stakeholders". Interaction is an important element of online learning (Parker 2020), especially in DE where the learner is geographically separated from the instructor (Moore 1989). Teaching tools such as e-portfolios thus provide space for instant communication and feedback to students.

Provision of feedback was also found to be of prime importance in many of the studies reviewed. Yang, Tai, and Lim (2016) argued that constructive feedback is a precursor for sustained learning support. Kabilan and Khan (2012) and Strydom and Barnard (2017) also reported that participants' learning and achievement were attained by feedback given by peers and the instructor. Feedback as the vehicle for reflection, helps to improve student's critical thinking skills (De Swardt et al. 2019; Mohamad, Embi, and Nordin 2016) and deep learning (Kabilan and Khan 2012; Lukitasari, Hasan, and Sukri 2020; Sellami 2017). The interdependency of these concepts is reported in the reviewed studies, indicating that reflection leads to self-directed learning (Mohamad, Embi, and Nordin 2016), critical thinking (De Swart et al. 2019; Thang, Lee, and Zulkifli 2012), and how meaningful feedback may improve learning (De Jager 2019; Harun and Jhee 2012).

\section{Continuous and Authentic Assessment}

If well designed, e-portfolios have the ability to offer continuous and authentic assessment. Yang, Tai, and Lim (2016) argued that e-portfolio use can be successful through coherent assessment design. Abd-Wahab et al. $(2016,7)$ argue that e-portfolios "provide students and educators with an assessment tool to improve academic success", while Kabilan and Khan (2012) believe that e-portfolios are more transparent and 
practical compared to the conventional tests. Therefore, when considering how to assess student learning, it is vital that assessment be designed to improve students' skills and understanding of course content. Thus, it is fundamental for assessment to be continuous and authentic requiring application of what students have learnt to a new situation, which demands judgement to determine what information and skills are relevant (Conrad and Openo 2018).

\section{Challenges of Adopting E-Portfolios in Higher Education}

Although some studies superficially mentioned challenges that are stumbling blocks for the effective adoption of e-portfolios in their countries, most of the included papers elaborated on the challenges they faced in their respective countries (Table 3). Most of the identified challenges include digital literacy of lecturers and students, internet connectivity, lack of digital devices, and the lack of awareness of e-portfolios in HE. The major challenge in many developing countries is the level of digital literacy that is necessary to develop quality e-portfolios that are supported by vigorous student-centred assessments approaches and methods that support meaningful learning in HE and DE. The lack of appropriate digital literacy was highlighted in the studies (Akleh and Wahab 2020; De Jager 2019; Lukitasari, Hasan, and Sukri 2020; Thang, Lee, and Zulkifli 2012); however, to mitigate this challenge, HEIs need to design innovative support and training strategies for both the lecturers and students.

The appropriate choice of e-portfolio software and platforms may also help to reduce the negative attitudes reported in various studies. The design look and feel, ease of access and use, and the ability to give instant feedback and to promote interaction will determine the successful implementation of e-portfolios. Linked to the challenges of access to data, devices and connectivity prevalent in developing countries is the importance to use e-portfolio applications, software and/or platforms that will encourage adoption and use of the e-portfolios by lecturers and learners.

Another major challenge reported in various studies is the perceived time and effort to develop e-portfolios, with Abd-Wahab et al. (2016) reporting that uploading large files was difficult and time-consuming for students. With the current cloud technologies (Vakaliuk et al. 2021), students may find it easier to upload big files onto their cloud platforms, which can be linked with their e-portfolios. The lecturers could also design tasks that allows small chunks of files to be uploaded at a time. Given that the internet connectivity and mobile data are some of the major challenges, particularly in rural areas (De Swardt et al. 2019; Abd-Wahab et al. 2016), it is important that e-portfolio tasks be creatively designed to minimise the amount of time needed for internet connection.

Assessing learning in online spaces has been one of the challenges. Harun and Jhee $(2012,249)$ argue that an "excessive amount of time is required to read all the blogs posts for the grading purposes", however, the technology is being constantly updated to improve automation and efficiency for online assessment and the ability to give instant feedback to students. Most of the identified challenges are generally similar in many 
developing countries (Table 3), however, in comparison to the identified benefits as outlined in Table 2, the e-portfolios seem to have much value to offer HEIs that want to innovate their teaching and learning. The Covid-19 pandemic had a great impact on many countries forcing many HEIs to migrate their teaching and learning activities to online spaces (Ogundokun et al. 2020). Creatively designed and executed e-portfolios may just be one of the possible solutions for lecturers and students during the pandemic.

\section{Conclusion}

This paper reported on a systematic review of peer-reviewed academic studies of eportfolios between 2010 and 2020 outlining the way in which e-portfolios could effectively be used as a tool for teaching and supporting learning in HE and DE. Inclusion and exclusion criteria were used to select studies from developing countries in Africa and Asia. The included studies strongly concur on the effectiveness of eportfolios and listed many benefits using e-portfolios as a teaching and support tool. However, most of the identified challenges are generic, have no bearing on e-portfolios, and can be solved by HEIs and their national governments. Constructivism and selfdirected learning theories were used to highlight the fact that e-portfolios are based on learning by doing which fosters many benefits for learners, including ownership of learning, gaining of multimedia and digital skills, collaborative skills and other vital skills necessary for twenty-first century students to function in an evolving digital age.

The 18 reviewed studies include various recommendations for the use of e-portfolios, mostly mentioning training and support as key to the successful implementation of eportfolios. Training is necessary to equip both instructors and students with relevant skills that motivate them and pave the way towards smooth adoption and use of eportfolios and that mitigate the prevalent challenges of digital literacy in developing countries' contexts. Introductory training workshops are especially beneficial for students and should effectively be conducted at the beginning of the course or module to teach them how to create their e-portfolios. Instructors also require training and continuous support to enhance their e-portfolio teaching skills.

Furthermore, HEIs, through a consultative-participatory approach, should choose easily accessible and user-friendly e-portfolio platforms that help to ensure a smooth transition. In conclusion, this study confirms the pedagogical affordances and many benefits which e-portfolios can offer $\mathrm{HE}$ and DE, and their relevancy in the present era.

\section{Acknowledgements}

We are grateful for the financial support from the UNESCO Chair on Open and Distance Learning at Unisa and the Women-In-Research grant. We also thank our colleagues in the Open Distance Learning Research Unit for providing constructive comments on our first draft, and Dr Melissa Bond at the EPPI-Centre, University College London, for her 
selfless help, guidance, and support with the EPPI-Reviewer software program during this research project.

\section{References}

Abd-Wahab, S. R. H., Adi Irfan Che-Ani, Suhana Johar, Khaidzir Ismail, and Mohd Zulhanif Abd-Razak. 2016. "EPortfolio: A Descriptive Survey for Contents and Challenges." International Journal of Emerging Technologies in Learning 11 (1). https://doi.org/10.3991/ijet.v11i01.4900.

Akleh, Aamal, and Rabab A. Wahab. 2020. "Effectiveness of Course Portfolio in Improving Course Quality at Higher Education." International Journal of Higher Education 9 (3): 39-48. https://doi.org/10.5430/ijhe.v9n3p39.

Amineh, Roya Jafari, and Hanieh Davatgari Asl. 2015. "Review of Constructivism and Social Constructivism." Journal of Social Sciences, Literature and Languages 1 (1): 9-16.

Baker-Doyle, Kira J., and Susan A. Yoon. 2020. "The Social Side of Teacher Education: Implications of Social Network Research for the Design of Professional Development." International Journal of Educational Research 101. https://doi.org/10.1016/j.ijer.2020.101563.

Barrett, H. 2011. “REAL EPortfolio Academy for K-12 Teachers.” Accessed 27 July 2021. http://electronicportfolios.com/academy/index.html.

Bassot, Barbara. 2015. The Reflective Practice Guide: An Interdisciplinary Approach to Critical Reflection. London: Routledge. https://doi.org/10.4324/9781315768298.

Bates, A. T. 2015. "Defining Skills for a Digital Age.” Accessed 27 July 2021. https://www.tonybates.ca/2015/04/20/defining-skills-for-a-digital-age.

Beckers, Jorrick, Diana Dolmans, and Jeroen van Merriënboer. 2016. "E-Portfolios Enhancing Students' Self-Directed Learning: A Systematic Review of Influencing Factors.” Australasian Journal of Educational Technology 32 (2). https://doi.org/10.14742/ajet.2528.

Bond, Melissa, Katja Buntins, Svenja Bedenlier, Olaf Zawacki-Richter, and Michael Kerres. 2020. "Mapping Research in Student Engagement and Educational Technology in Higher Education: A Systematic Evidence Map.” International Journal of Educational Technology in Higher Education 17 (1): 2. https://doi.org/10.1186/s41239-019-0176-8.

Boulton, Helen. 2014. "EPortfolios beyond Pre-Service Teacher Education: A New Dawn?" European Journal of Teacher Education 37 (3): 374-89. https://doi.org/10.1080/02619768.2013.870994. 
Carl, Arend, and Sonja Strydom. 2017. "E-Portfolio as Reflection Tool during Teaching Practice: The Interplay between Contextual and Dispositional Variables." South African Journal of Education 37 (1). https://doi.org/10.15700/saje.v37n1a1250.

Chau, Juliana, and Gary Cheng. 2010. "Towards Understanding the Potential of E-Portfolios for Independent Learning: A Qualitative Study.” Australasian Journal of Educational Technology 26 (7). https://doi.org/10.14742/ajet.1026.

Chaudhuri, Tushar, and Béatrice Cabau, eds. 2017. E-Portfolios in Higher Education: A Multidisciplinary Approach. New York: Springer. https://doi.org/10.1007/978-981-103803-7.

Cheng, Gary, and Juliana Chau. 2013. "Exploring the Relationship between Students' SelfRegulated Learning Ability and their EPortfolio Achievement." Internet and Higher Education 17: 9-15. https://doi.org/10.1016/j.iheduc.2012.09.005.

Chugh, Ritesh, and Umar Ruhi. 2018. "Social Media in Higher Education: A Literature Review of Facebook." Education and Information Technologies 23 (2): 605-16.

https://doi.org/10.1007/s10639-017-9621-2.

Conrad, Dianne, and Jason Openo. 2018. Assessment Strategies for Online Learning: Engagement and Authenticity. Athabasca University Press. https://doi.org/10.15215/aupress/9781771992329.01.

De Jager, Thelma. 2019. “Impact of EPortfolios on Science Student-Teachers' Reflective Metacognitive Learning and the Development of Higher-Order Thinking Skills." Journal of University Teaching and Learning Practice 16 (3): 3.

Deslandes, Suely, and Tiago Coutinho. 2020. "Social Research in Digital Environments in COVID-19 Times: Theoretical and Methodological Notes." Cadernos de Saúde Pública 36. https://doi.org/10.1590/0102-311x00223120.

De Swardt, Magdaleen, Louis S. Jenkins, Klaus B. von Pressentin, and Robert Mash. 2019. "Implementing and Evaluating an E-Portfolio for Postgraduate Family Medicine Training in the Western Cape, South Africa." BMC Medical Education 19 (1): 1-13. https://doi.org/10.1186/s12909-019-1692-x.

Ebil, S. H., S. M. Salleh, and M. Shahrill. 2020. "The Use of E-Portfolio for Self-Reflection to Promote Learning: A Case of TVET Students." Education and Information Technologies 25 (6): 5797-814.

EPPI-Centre. 2021. “About EPPI-Reviewer.” Accessed 27 July 2021. https://eppi.ioe.ac.uk/cms/Default.aspx?tabid=2967.

FitzPatrick, Mary Anne, and Dorothy Spiller. 2010. “The Teaching Portfolio: Institutional Imperative or Teacher's Personal Journey?" Higher Education Research and Development 29 (2): 167-78. https://doi.org/10.1080/07294360903470985. 
Garrison, D. Randy. 1997. "Self-Directed Learning: Toward a Comprehensive Model.” Adult Education Quarterly 48 (1): 18-33. https://doi.org/10.1177/074171369704800103.

Gurukkal, Rajan. 2020. “Will COVID-19 Turn Higher Education into another Mode?” 89-96. https://doi.org/10.1177/2347631120931606.

Harun, R. N. S. R., and Y. S. Jhee. 2012. "Enhancing Learning through Process E-Portfolios among ESL Graduate Students in an Education University." International Journal of Learning 18 (10): 235-52. https://doi.org/10.18848/1447-9494/CGP/v18i10/47785.

Herbert, Elizabeth A. 1998. "Lessons Learned about Student Portfolios.” Phi Delta Kappan 79 (8): 583.

Jimoyiannis, Athanassios. 2012. "Developing a Pedagogical Framework for the Design and the Implementation of E-Portfolios in Educational Practice." Themes in Science and Technology Education 5: 107-32.

Kabilan, Muhammad Kamarul, and Mahbub Ahsan Khan. 2012. “Assessing Pre-Service English Language Teachers' Learning Using E-Portfolios: Benefits, Challenges and Competencies Gained." Computers and Education 58 (4): 1007-20. https://doi.org/10.1016/j.compedu.2011.11.011.

Knowles, Malcolm S. 1975. "Self-Directed Learning: A Guide for Learners and Teachers."

Light, Tracy Penny, Helen L. Chen, and John C. Ittelson. 2012. Documenting Learning with EPortfolios: A Guide for College Instructors. John Wiley and Sons.

Lukitasari, Marheny, Rusdi Hasan, and Akhmad Sukri. 2020. "The Effect of E-Portfolio on Biological Concepts Understanding and Responses of Students with Different Academic Achievement Levels.” International Journal of Instruction 13 (1): 685-94. https://doi.org/10.29333/iji.2020.13144a.

Mapundu, M., and M. Musara. 2019. "E-Portfolios as a Tool to Enhance Student Learning Experience and Entrepreneurial Skills." South African Journal of Higher Education 33 (6): 191-214. https://doi.org/10.20853/33-6-2990.

Mohamad, Syamsul Nor Azlan, Mohamed Amin Embi, and Norazah Mohd Nordin. 2016. "EPortfolio Reflective Learning Strategies to Enhance Research Skills, Analytical Ability, Creativity and Problem-Solving." Asian Social Science 12 (10): 228-36. https://doi.org/10.5539/ass.v12n10p228.

Moher, D., and A. Liberati, J. Tetzlaff, and D. G. Altman. 2009. "Preferred Reporting Items for Systematic Reviews and Meta-Analyses: The PRISMA Statement.” BMJ 339. https://doi.org/10.1136/bmj.b2535.

Moore, Michael G. 1989. “Three Types of Interaction.” American Journal of Distance Education 3 (2): 1-6. https://doi.org/10.1080/08923648909526659. 
Morris, Thomas Howard. 2020. "Creativity through Self-Directed Learning: Three Distinct Dimensions of Teacher Support.” International Journal of Lifelong Education 39 (2): 16878. https://doi.org/10.1080/02601370.2020.1727577.

Moye, Johnny J., William E. Dugger Jr, and Kendall N. Starkweather. 2014. "Is 'Learning by Doing' Important? A Study of Doing-Based Learning: This is the Second in a Series of Articles Discussing the Doing-Based Learning Study." Technology and Engineering Teacher 74 (3): 22.

Ogundokun, Roseline O., Adewale F. Lukman, Golam B. M. Kibria, Joseph B. Awotunde, and Benedita B. Aladeitan. 2020. "Predictive Modelling of COVID-19 Confirmed Cases in Nigeria." Infectious Disease Modelling 5: 543-8. https://doi.org/10.1016/j.idm.2020.08.003.

Oh, Jae-Eun, Yuet Kai Chan, and Kyulee Viviane Kim. 2020. "Social Media and E-Portfolios: Impacting Design Students' Motivation through Project-Based Learning." IAFOR Journal of Education 8 (3). https://doi.org/10.22492/ije.8.3.03.

Parker, Angie. 2020. "Interaction in Distance Education: The Critical Conversation.” AACE Review 13-17.

Pérez, Jorge, Jessica Díaz, Javier Garcia-Martin, and Bernardo Tabuenca. 2020. "Systematic Literature Reviews in Software Engineering - Enhancement of the Study Selection Process using Cohen's Kappa Statistic.” Journal of Systems and Software 168. https://doi.org/10.1016/j.jss.2020.110657.

Pham, Mai T., Andrijana Rajić, Judy D. Greig, Jan M. Sargeant, Andrew Papadopoulos, and Scott A. McEwen. 2014. "A Scoping Review of Scoping Reviews: Advancing the Approach and Enhancing the Consistency." Research Synthesis Methods 5 (4): 371-85. https://doi.org/10.1002/jrsm.1123.

Polonoli, Keith E. 2000. "Defining the Role of the Digital Portfolio in Teacher Education." ERIC ED447806.

Reese, Hayne W. 2011. “The Learning-By-Doing Principle.” Behavioral Development Bulletin 17 (1): 1. https://doi.org/10.1037/h0100597.

Roder, John, and Mark Brown. 2009. "What Leading Educators Say about Web 2.0, PLEs and E-Portfolios in the Future." Same Places, Different Spaces. Proceedings Ascilite Auckland $870-82$.

Rodgers, Michael, Darla Runyon, David Starrett, and Roger von Holzen. 2006. "Teaching the 21st Century Learner." In 22nd Annual Conference on Distance Teaching and Learning, $1-4$.

Sellami, Hedia. 2017. "Use of the EPortfolio by Adults in the Tunisian Continuous Education Context." Africa Education Review 14 (2): 37-51. https://doi.org/10.1080/18146627.2017.1279014. 
Shroff, Ronnie H., John Trent, and Eugenia M. W. Ng. 2013. "Using E-Portfolios in a Field Experience Placement: Examining Student-Teachers' Attitudes towards Learning in Relation to Personal Value, Control and Responsibility." Australasian Journal of Educational Technology 29 (2). https://doi.org/10.14742/ajet.51.

Strydom, Sonja, and Magda Barnard. 2017. “A Tale of Two Faculties: Exploring Student Experiences of E-Portfolio Implementation as a Vehicle of Reflective Learning at Stellenbosch University." Independent Journal of Teaching and Learning 12 (2): 78-91.

TeachOnline. 2014. "Documenting Learning: Using E-Portfolios in Visual Arts and the Built Environment at the University of Windsor." Accessed 27 July 2021. https://teachonline.ca/pockets-innovation/documenting-learning-using-e-portfolios-visualarts-and-built-environment.

Thang, Siew Ming, Yit Sim Lee, and Nurul Farhana Zulkifli. 2012. "The Role of the Electronic Portfolio in Enhancing Information and Communication Technology and English Language Skills: The Voices of Six Malaysian Undergraduates." Computer Assisted Language Learning 25 (3): 277-93. https://doi.org/10.1080/09588221.2012.655299.

Vakaliuk, T. A., O. M. Spirin, N. M. Lobanchykova, L. A. Martseva, I. V. Novitska, and V. V. Kontsedailo. 2021. "Features of Distance Learning of Cloud Technologies for the Organization Educational Process in Quarantine." Journal of Physics: Conference Series 1840 (1): 012051. https://doi.org/10.1088/1742-6596/1840/1/012051.

Van Wyk, Micheal M. 2017. 'Exploring Student Teachers' Views on Eportfolios as an Empowering Tool to Enhance Self-Directed Learning in an Online Teacher Education Course." Australian Journal of Teacher Education 42 (6): 1. https://doi.org/10.14221/ajte.2017v42n6.1.

Yang, Min, Mui Tai, and Cher Ping Lim. 2016. "The Role of E-Portfolios in Supporting Productive Learning." British Journal of Educational Technology 47 (6): 1276-86. https://doi.org/10.1111/bjet.12316.

Zawacki-Richter, Olaf, Aras Bozkurt, Uthman Alturki, and Ahmed Aldraiweesh. 2018. "What Research says about MOOCs - An Explorative Content Analysis." International Review of Research in Open and Distributed Learning 19 (1). https://doi.org/10.19173/irrodl.v19i1.3356. 